\title{
Wild Brazilian Mustard (Brassica juncea L.) Seed Oil Methyl Esters as Biodiesel Fuel
}

\author{
Gulab N. Jham · Bryan R. Moser · Shailesh N. Shah · Ronald A. Holser · Onkar D. Dhingra • \\ Steven F. Vaughn · Mark A. Berhow · Jill K. Winkler-Moser · Terry A. Isbell · Ray K. Holloway · \\ Erin L. Walter · Ricardo Natalino · Jason C. Anderson · David M. Stelly
}

Received: 26 November 2008/Revised: 12 June 2009/Accepted: 15 June 2009/Published online: 3 July 2009

(C) AOCS 2009

\begin{abstract}
Wild mustard (Brassica juncea L.) oil is evaluated as a feedstock for biodiesel production. Biodiesel was obtained in $94 \mathrm{wt} . \%$ yield by a standard transesterification procedure with methanol and sodium methoxide catalyst. Wild mustard oil had a high content of erucic
\end{abstract}

Disclaimer: Product names are necessary to report factually on available data; however, the USDA neither guarantees nor warrants the standard of the product, and the use of the name by USDA implies no approval of the product to the exclusion of others that may also be suitable.

\section{G. N. Jham $(\bowtie) \cdot$ O. D. Dhingra \\ Departamento de Fitopatologia, \\ Universidade Federal de Viçosa, \\ Viçosa, MG 36.570-000, Brazil \\ e-mail: gulab@ufv.br}

B. R. Moser $(\varangle)$ - S. N. Shah · S. F. Vaughn •

M. A. Berhow - J. K. Winkler-Moser · T. A. Isbell .

R. K. Holloway · E. L. Walter

United States Department of Agriculture,

Agricultural Research Service, National Center for Agricultural

Utilization Research, 1815N University St, Peoria,

IL 61604, USA

e-mail: Bryan.Moser@ars.usda.gov

\section{R. A. Holser}

United States Department of Agriculture,

Agricultural Research Service,

Richard B. Russell Research Center, 950 College Station Rd,

Athens, GA 30605, USA

R. Natalino

Departamentos de Quimica, Universidade Federal de Viçosa,

Viçosa, MG 36.570-000, Brazil

J. C. Anderson - D. M. Stelly

Department of Soil and Crop Science,

Texas A \& M University, 370 Olsen Blvd,

College Station, TX 77843, USA
(13(Z)-docosenoic; 45.7 wt.\%) acid, with linoleic $(9(Z)$, 12(Z)-octadecadienoic; $14.2 \mathrm{wt} . \%)$ and linolenic $(9(Z)$, $12(Z), 15(Z)$-octadecatrienoic; $13.0 \mathrm{wt} . \%)$ acids comprising most of the remaining fatty acid profile. The cetane number, kinematic viscosity, and oxidative stability (Rancimat method) of the methyl esters was $61.1,5.33 \mathrm{~mm}^{2} \mathrm{~s}^{-1}$ $\left(40{ }^{\circ} \mathrm{C}\right)$ and $4.8 \mathrm{~h}\left(110^{\circ} \mathrm{C}\right)$, respectively. The cloud, pour and cold filter plugging points were $4,-21$ and $-3^{\circ} \mathrm{C}$, respectively. Other properties such as acid value, lubricity, free and total glycerol content, iodine value, Gardner color, specific gravity, as well as sulfur and phosphorous contents were also determined and are discussed in light of biodiesel standards ASTM D6751 and EN 14214. Also reported are the properties and composition of wild mustard oil, along with identification of wild mustard collected in Brazil as Brassica juncea $\mathrm{L}$. $(2 \mathrm{n}=36)$ as opposed to the currently accepted Sinapis arvensis $\mathrm{L} .(2 \mathrm{n}=18)$ classification. In summary, wild mustard oil appears to be an acceptable feedstock for biodiesel production.

Keywords Biodiesel - Brassica juncea - Fatty acid methyl esters · Phytosterols · Tocopherols ·

Transesterification $\cdot$ Wild mustard

\section{Introduction}

Biodiesel has attracted considerable interest as a substitute or blend component for conventional petroleum diesel fuel (petrodiesel). Biodiesel, defined as simple mono-alkyl esters of long-chain fatty acids prepared from vegetable oils or animal fats, possesses a number of technical advantages over petrodiesel, such as derivation from renewable and domestic feedstocks, displacement of imported petroleum, inherent lubricity, essentially no 
Table 1 Selected specifications from American (ASTM D6751) and European Union (EN 14214) biodiesel standards

\begin{tabular}{lll}
\hline & ASTM D6751 & EN 14214 \\
\hline Acid value $\left(\mathrm{mg} \mathrm{KOH} \mathrm{g}^{-1}\right)$ & $<0.50$ & $<0.50$ \\
Free glycerol (mass \%) & $<0.020$ & $<0.020$ \\
Total glycerol (mass \%) & $<0.240$ & $<0.250$ \\
Cloud point $\left({ }^{\circ} \mathrm{C}\right)$ & Report & $-{ }^{\mathrm{a}}$ \\
Pour point $\left({ }^{\circ} \mathrm{C}\right)$ & - & - \\
Cold filter plugging point $\left({ }^{\circ} \mathrm{C}\right)$ & - & Variable \\
Oxidative stability & & \\
Induction period, $110{ }^{\circ} \mathrm{C}(\mathrm{h})$ & $>3$ & $>6$ \\
Onset temperature $\left({ }^{\circ} \mathrm{C}\right)$ & - & - \\
Kinematic viscosity, $40{ }^{\circ} \mathrm{C}\left(\mathrm{mm}^{2} \mathrm{~s}^{-1}\right)$ & $1.9-6.0$ & $3.5-5.0$ \\
Specific gravity & - & - \\
Sulfur (ppm) & $<15$ & $<10$ \\
Phosphorous $(\operatorname{mass} \%)$ & $<0.001$ & $<0.001$ \\
Cetane number & $>47$ & $>51$ \\
Wear scar, HFRR, $60{ }^{\circ} \mathrm{C}(\mu \mathrm{m})$ & $-{ }^{\mathrm{c}}$ & $-{ }^{\mathrm{c}}$ \\
Gardner color & - & - \\
odine value $(\mathrm{g} \mathrm{I} / 100 \mathrm{~g})$ & - & $<120$ \\
\hline
\end{tabular}

${ }^{a}$ Not specified

b Variable by location and time of year

c Maximum wear scars of 520 and $460 \mu \mathrm{m}$ are specified in petrodiesel standards ASTM D975 and EN 590, respectively

sulfur content, superior flash point and biodegradability, reduced toxicity, as well as a reduction in most regulated exhaust emissions. Important disadvantages of biodiesel include inferior oxidative and storage stability, lower volumetric energy content, inferior low temperature operability, and higher $\mathrm{NO}_{x}$ exhaust emissions [1, 2]. High feedstock cost is a serious economic disadvantage of biodiesel, as up to $85 \%$ of production expenses are a result of feedstock acquisition [3]. As a result, alternatives to expensive and potentially cost-prohibitive commodity feedstocks such as refined canola, corn, soybean, and palm oils are critical to the continued survival and expansion of the biodiesel industry.

Wild mustard, also known as field mustard, is an annual herbaceous plant belonging to the Brassicaceae family that is an invasive agricultural pest (weed) to winter crops in southern and southeastern Brazil. Currently not utilized commercially, it also grows abundantly in orchards, plantation crops, wastelands, and along roadsides. Morphologically, wild mustard has been identified as Sinapis arvensis L. [4]. Recent studies demonstrated that defatted wild mustard seed meal efficiently controlled root knot nematodes during coffee seedling production when used as a soil amendment [5]. The oil left over after seed meal preparation may serve as an inexpensive feedstock for biodiesel production. The Brassicaceae family is a rich source of feedstocks for biodiesel production, as evidenced by recent reports on Brassica alba L., B. carinata L., Camelina sativa L., and Raphanus sativus L. oils, among others [2]. Canola (or rapeseed, B. napus L.) has already gained widespread acceptance as a common commodity feedstock for biodiesel production.

Biodiesel must be satisfactory according to accepted fuel standards (Table 1) such as ASTM D6751 in the United States or the Committee for Standardization (CEN) standard EN 14214 in Europe before combustion in compression-ignition (diesel) engines. The objective of the current investigation was to prepare methyl esters from wild mustard oil (WMO) and to compare their fuel properties to the biodiesel fuel standards ASTM D6751 and EN 14124 as well as to soybean oil methyl esters (SME). Identification of wild mustard through determination of its chromosome number was of interest. The chemical composition (fatty acid, tocopherol, and phytosterol profiles) and physical properties of WMO were of additional interest.

\section{Materials and methods}

\section{Materials}

Wild mustard seeds were harvested from mature plants growing on fallow land on the campus of the Universidade Federal de Viçosa, Viçosa, MG, Brazil. Refined, bleached, and deodorized (RBD) soybean oil (SBO) was purchased from KIC Chemicals, Inc. (New Platz, NY) and used as received. tocopherol standards ( $\geq 97 \%$ purity), as well as stigmasterol and $5 \alpha$-cholestane, were obtained from Matreya, LLC (Pleasant Gap, PA). Campesterol and brassicasterol were purchased from Steraloids, Inc. (Newport, RI). $\mathrm{N}, \mathrm{O}$-Bis(trimethylsilyl)-fluoroacetamide with $1 \%$ trimethyl-chlorosilane (BSTFA $+1 \%$ TMCS) was purchased from Regis Technologies, Inc. (Morton Grove, IL). Each phytosterol standard was $\geq 97 \%$ purity. Fatty acid methyl ester (FAME) standards were purchased from Nu-Chek Prep, Inc. (Elysian, MN). All other chemicals and reagents were obtained from Sigma-Aldrich Corp. (St. Louis, MO) and used as received.

\section{Chromosome number}

Wild mustard seeds were planted in a greenhouse in sterilized soil without fertilizer. After 40 days, the root tips were excised and pretreated with saturated aqueous $\alpha$-monobromonapthalene for $2 \mathrm{~h}$ in the dark and immediately fixed and stored in ethanol:acetic acid (4:1). Somatic metaphase chromosome spreads were prepared from greenhouse-grown seedling root tips $[6,7]$ using a 50-min enzymatic treatment for cell wall digestion. Cells were 
observed immediately after slide preparation on a Zeiss microscope using phase contrast microscopy. Given the presence of somatic metaphase spreads, one drop of VECTASHIELD mounting medium containing $4^{\prime}, 6$-diamidino-2-phenylindole (DAPI) was utilized to stain the chromatin of the chromosomes, allowing the somatic spreads to be observed using fluorescence microscopy. Images were obtained with an Olympus AX-70 epifluorescence microscope equipped with standard filter cubes, a Peltier-cooled monochrome 1.3 mega-pixel Sensys camera, and Mac-Probe v.4.23 digital imaging system.

\section{Oil Extraction}

Wild mustard seeds were ground in a coffee grinder and oil was extracted with hexane for $24 \mathrm{~h}$ in a Soxhlet apparatus. Hexane was removed from the oil by rotary evaporation under reduced pressure $\left(20 \mathrm{mbar} ; 30^{\circ} \mathrm{C}\right)$. For determination of total oil content, $10.0 \mathrm{~g}$ triplicates of ground seeds were extracted for $24 \mathrm{~h}$ with a Soxhlet apparatus, and after hexane was removed under reduced pressure the weights of the residual oils were calculated.

\section{Tocopherol Content}

Tocopherols were quantified by HPLC according to AOCS official method Ce 8-89 using a hexane/2-propanol mobile phase on an Inertsil (Varian, Walnut Creek, CA) silica column $(5 \mu \mathrm{m}, 150 \AA, 250 \mathrm{~mm} \times 4.6 \mathrm{~mm}$ i.d.), Varian HPLC Pro-Star model 230 pump, model 410 auto sampler, and model 363 fluorescence detector using excitation and emission wavelengths of 290 and $330 \mathrm{~nm}$, respectively. Tocopherol peaks were identified by comparison to the retention times of reference standards. Each determination was run in triplicate and mean values are reported.

\section{Phytosterol Content}

Samples were saponified and phytosterols extracted essentially as described previously [8]. After saponification, phytosterols were manually injected onto a Varian 3400 GC equipped with an FID and a Supelco (Bellefonte, PA) $\mathrm{SPB}^{\mathrm{TM}}-1701(30 \mathrm{~m} \times 0.25 \mathrm{~mm} \times 0.25 \mu \mathrm{m})$ capillary column. Helium was used as the carrier gas with a 1:50 injector split. The injector and detector temperatures were 270 and $290{ }^{\circ} \mathrm{C}$, respectively. The column oven initial temperature was $250{ }^{\circ} \mathrm{C}$ for $0.5 \mathrm{~min}$, increased at $10^{\circ} \mathrm{C} \mathrm{min}^{-1}$ to $270{ }^{\circ} \mathrm{C}$ and held for $27 \mathrm{~min}$, then increased at $10^{\circ} \mathrm{C} \mathrm{min}^{-1}$ to $280{ }^{\circ} \mathrm{C}$ and held for $3.5 \mathrm{~min}$. Phytosterols were identified by comparison to the retention times (relative to the internal standard, $5 \alpha$-cholestane) of available reference standards. Phytosterols without commercially available standards, such as $\delta 5$-avenasterol, were identified by their relative retention times compared to literature [8], and by comparison with samples known to contain those phytosterols. Quantification was carried out by the internal standard method developed with available standards. For phytosterols with no available commercial standard, the response factor for $\beta$-sitosterol was used for quantification. Each determination was run in triplicate and mean values are reported.

\section{Methanolysis of Wild Mustard Oil}

Methanolysis of WMO was performed in a $500-\mathrm{mL}$ threenecked round bottom flask connected to a reflux condenser and a mechanical magnetic stirrer set at 1,200 rpm. Initially, WMO $(300 \mathrm{~g}, 200 \mathrm{~mL}, 0.306 \mathrm{~mol})$ and methanol ( $75 \mathrm{~mL}, 1.84 \mathrm{~mol}$; 6:1 mole ratio) were added to the flask and heated to $60{ }^{\circ} \mathrm{C}$ (internal reaction temperature monitored by digital temperature probe), followed by addition of $1.50 \mathrm{~g}$ of a $25 \mathrm{wt} . \%$ solution of sodium methoxide in methanol. After reacting for $1.5 \mathrm{~h}$ the mixture was equilibrated to room temperature and transferred to a separatory funnel. The lower glycerol phase was removed by gravity separation ( $>2 \mathrm{~h}$ settling time) followed by removal of methanol from the crude methyl ester phase by reduced pressure $\left(20 \mathrm{mbar} ; 30^{\circ} \mathrm{C}\right)$ rotary evaporation. The crude methyl esters were washed until a neutral $\mathrm{pH}$ was obtained with distilled water $(4 \times 20 \mathrm{~mL})$ and dried with magnesium sulfate to provide wild mustard oil methyl esters (WMME, 94 wt.\% yield). ${ }^{1} \mathrm{H}$ NMR $\left(500 \mathrm{MHz}, \mathrm{CDCl}_{3}\right): \delta$ $5.35\left(\mathrm{~m}, 2 \mathrm{H}\right.$, vinyl), $3.67\left(\mathrm{~s}, 3 \mathrm{H},-\mathrm{OCH}_{3}\right), 2.80(\mathrm{~m}, 2 \mathrm{H}$, bisallylic), 2.31 (t, $2 \mathrm{H}$, allylic), $2.03(\mathrm{~m}, 2 \mathrm{H}, \alpha$ to ester), 1.63 (m, $2 \mathrm{H}, \beta$ to ester), $1.28(\mathrm{~m}, 28 \mathrm{H}$, methylene), $0.90(\mathrm{t}, 3 \mathrm{H}$, terminal methyl). FT-IR (neat): 3008, 2923, 2853, 1742, $1463,1435,1362,1245,1195,1170,1120,1104,1061$, $1015,881,843,722 \mathrm{~cm}^{-1}$. Soybean oil methyl esters (SME) were prepared in a similar fashion in essentially quantitative (>98 wt.\%) yield. ${ }^{1} \mathrm{H}-\mathrm{NMR} \quad(500 \mathrm{MHz}$, $\left.\mathrm{CDCl}_{3}\right): \delta 5.36\left(\mathrm{~m}, 2 \mathrm{H}\right.$, vinyl), $3.67\left(\mathrm{~s}, 3 \mathrm{H},-\mathrm{OCH}_{3}\right), 2.78$ (m, 2H, bis-allylic), 2.31 (t, 2H, allylic), $2.05(\mathrm{~m}, 2 \mathrm{H}, \alpha$ to ester), 1.63 ( $\mathrm{m}, 2 \mathrm{H}, \beta$ to ester), 1.29 ( $\mathrm{m}, 28 \mathrm{H}$, methylene), 0.90 (t, 3H, terminal methyl). FT-IR (neat): 3009, 2923, 2854, 1741, 1459, 1435, 1361, 1244, 1195, 1170, 1121, $1016,913,883,844,722 \mathrm{~cm}^{-1}$.

\section{Fatty Acid Profile by GC}

Fatty acid methyl esters (FAME) of WMME and SME were separated using a Varian 8400 GC equipped with an FID detector and a SP2380 (Supelco) column ( $30 \mathrm{~m} \times 0.25 \mathrm{~mm}$ i.d., $0.20 \mu \mathrm{m}$ film thickness). Carrier gas was $\mathrm{He}$ at $1 \mathrm{~mL} \min ^{-1}$. The oven temperature was initially held at $150{ }^{\circ} \mathrm{C}$ for $15 \mathrm{~min}$, increased to $210{ }^{\circ} \mathrm{C}$ at 
$2{ }^{\circ} \mathrm{C} \min ^{-1}$, increased to $220{ }^{\circ} \mathrm{C}$ at $50{ }^{\circ} \mathrm{C} \mathrm{min}{ }^{-1}$, then held for $10 \mathrm{~min}$. The injector and detector temperatures were 240 and $270{ }^{\circ} \mathrm{C}$, respectively. FAME peaks were identified by comparison to the retention times of reference standards with known double bond positions. Each FAME determination was run in triplicate and average values are reported.

\section{NMR and FT-IR Spectroscopy}

${ }^{1} \mathrm{H}-\mathrm{NMR}$ data were recorded using a Bruker AV-500 spectrometer (Billerica, MA) operating at $500 \mathrm{MHz}$ using a 5-mm broadband inverse $\mathrm{Z}$-gradient probe in $\mathrm{CDCl}_{3}$ (Cambridge Isotope Laboratories, Andover, MA, USA) as solvent. FT-IR spectra were recorded on a Thermo-Nicolet Nexus 470 FTIR spectrometer (Madison, WI) with a Smart ARK accessory containing a $45 \mathrm{ZeSe}$ trough in a scanning range of $650-4,000 \mathrm{~cm}^{-1}$ for 64 scans at a spectral resolution of $4 \mathrm{~cm}^{-1}$.

Free and Total Glycerol Determination of Methyl Esters by GC

Free and total glycerol content was determined according to ASTM standard D6584 employing an Agilent (Santa Clara, CA) model 7890A GC-FID equipped with a model 7683B series injector and an Agilent D8-5HT (15 $\mathrm{m} \times 0.32 \mathrm{~mm}$ i.d., $0.10 \mu \mathrm{m}$ film thickness) column with cool on column injection. Carrier gas was $\mathrm{He}$ at $3 \mathrm{~mL} \mathrm{~min}^{-1}$. The oven temperature was initially held at $50{ }^{\circ} \mathrm{C}$ for $1 \mathrm{~min}$, increased to $190{ }^{\circ} \mathrm{C}$ at $15^{\circ} \mathrm{C} \mathrm{min}{ }^{-1}$, then increased to $230{ }^{\circ} \mathrm{C}$ at $7{ }^{\circ} \mathrm{C} \mathrm{min}{ }^{-1}$, followed by an increase to $390{ }^{\circ} \mathrm{C}$ at $30^{\circ} \mathrm{C} \mathrm{min}{ }^{-1}$, which was then held for $10 \mathrm{~min}$. The detector temperature was set to $390{ }^{\circ} \mathrm{C}$. Free and total glycerol quantification was made by comparison to external calibration curves as described in the official method.

\section{Physical Properties of Wild Mustard Oil and Methyl Esters}

Cloud $\left(\mathrm{CP},{ }^{\circ} \mathrm{C}\right)$ and pour point $\left(\mathrm{PP},{ }^{\circ} \mathrm{C}\right)$ determinations were made following ASTM standards D5773 and D5949, respectively, using a model PSA-70S Phase Technology Analyzer (Richmond, BC, Canada). Cloud and pour points were rounded to the nearest whole degree $\left({ }^{\circ} \mathrm{C}\right)$. For a greater degree of accuracy, PP measurements were done with a resolution of $1{ }^{\circ} \mathrm{C}$ instead of the specified $3{ }^{\circ} \mathrm{C}$ increment. Cold filter plugging points (CFPP, ${ }^{\circ} \mathrm{C}$ ) were measured in accordance to ASTM standard D6371 utilizing an ISL Automatic CFPP Analyzer model FPP 5Gs (Houston, TX). Each sample was run in triplicate and mean values are reported.
Kinematic viscosity $\left(v, \mathrm{~mm}^{2} \mathrm{~s}^{-1}\right)$ was determined with Cannon-Fenske viscometers (Cannon Instrument Co., State College, PA) at 25,40 , and $100{ }^{\circ} \mathrm{C}$ in accordance to ASTM standard D445. The viscosity index (VI) was calculated from kinematic viscosity data $\left(40\right.$ and $\left.100{ }^{\circ} \mathrm{C}\right)$ following ASTM standard D2270. Specific gravity (SG) was determined at 25 and $40{ }^{\circ} \mathrm{C}$ utilizing AOCS official method Cc 10a-25 using a Kimax $25 \mathrm{~mL}$ gravity pycnometer from Kimble Chase Life Science and Research Products (Vineland, NJ). All experiments were run in triplicate and mean values are reported.

Lubricity determinations were performed at $60{ }^{\circ} \mathrm{C}$ $\left( \pm 1{ }^{\circ} \mathrm{C}\right)$ according to ASTM standard D6079 using a highfrequency reciprocating rig (HFRR) lubricity tester (PCS Instruments, London, England) via Lazar Scientific (Granger, IN). Reported wear scars $(\mu \mathrm{m})$ were the result of measuring the maximum lengths of the $x$ - and $y$-axes of each wear scar using a Prior Scientific (Rockland, MA, USA) Epimat model M4000 microscope, followed by calculating the average of these maximum values. All experiments were run in duplicate and mean values are reported.

Induction period (IP, h) was measured in accordance to EN 14112 utilizing a Metrohm USA, Inc. (Riverview, FL) model 743 Rancimat instrument. The flow rate of air through $3 \pm 0.01 \mathrm{~g}$ of methyl esters was $10 \mathrm{~L} \mathrm{~h}^{-1}$ with a block temperature of $110{ }^{\circ} \mathrm{C}$ and a correction factor $(\Delta T)$ of $1.5^{\circ} \mathrm{C}$. The glass conductivity measuring vessel contained $50 \pm 0.1 \mathrm{~mL}$ of deionized water. Each sample was run in triplicate and mean values are reported.

Oxidation onset temperature $\left(\mathrm{OT},{ }^{\circ} \mathrm{C}\right)$ was determined using a DSC 2910 thermal analyzer from TA Instruments (Newcastle, DE). Typically, a $2 \mu \mathrm{L}$ sample, resulting in a film thickness of $<1 \mathrm{~mm}$, was placed in an aluminum pan hermetically sealed with a pinhole lid and oxidized with pressurized (1378.95 kPa; 200 psi) dry air (Gateway Airgas, St. Louis, MO) in the module with a heating rate of $10{ }^{\circ} \mathrm{C} \mathrm{min}{ }^{-1}$ from 50 to $350{ }^{\circ} \mathrm{C}$. A computer-generated plot of heat flow (W/g) versus temperature $\left({ }^{\circ} \mathrm{C}\right)$ was used to graphically determine OT. Each sample was run in triplicate and average values rounded to the nearest tenth of a degree are reported.

Acid value ( $\mathrm{AV}, \mathrm{mg} \mathrm{KOH} \mathrm{g}{ }^{-1}$ ) titrations were performed as described in AOCS official method Cd 3d-63 using a Metrohm 836 Titrando (Westbury, NY) autotitrator equipped with a model 801 stirrer and Solvotrode electrode. The official method was modified for scale to use $2 \mathrm{~g}$ of sample and $0.02 \mathrm{M} \mathrm{KOH}$. The titration endpoint was automatically determined and visually verified using a phenolphthalein indicator. Each sample was run in triplicate and mean values are reported.

Iodine value ( $\mathrm{IV}, \mathrm{g} \mathrm{I}_{2} / 100 \mathrm{~g}$ ) was calculated from the fatty acid (FA) profile using AOCS official method Cd 1c85. Derived cetane number (DCN) was determined by 
Table 2 Fatty acid composition (wt.\%) of wild mustard oil (WMO), with soybean oil (SBO) shown for comparison

\begin{tabular}{|c|c|c|}
\hline Fatty acid ${ }^{\mathrm{a}}$ & WMO & SBO \\
\hline $\mathrm{C} 14: 0$ & 0.1 & 0.1 \\
\hline C16:0 & 2.6 & 11.7 \\
\hline $\mathrm{C} 16: 19 \mathrm{c}$ & 0.2 & - \\
\hline C18:0 & 0.9 & 3.8 \\
\hline $\mathrm{C} 18: 19 \mathrm{c}$ & 6.8 & 22.0 \\
\hline $\mathrm{C} 18: 111 \mathrm{c}$ & 1.0 & 1.4 \\
\hline $\mathrm{C} 18: 29 \mathrm{c}, 12 \mathrm{c}$ & 14.2 & 52.6 \\
\hline $\mathrm{C} 18: 39 \mathrm{c}, 12 \mathrm{c}, 15 \mathrm{c}$ & 13.0 & 7.7 \\
\hline C20:0 & 0.8 & 0.2 \\
\hline $\mathrm{C} 20: 15 \mathrm{c}$ & 0.1 & - \\
\hline $\mathrm{C} 20: 111 \mathrm{c}$ & 5.3 & 0.2 \\
\hline $\mathrm{C} 20: 211 \mathrm{c}, 14 \mathrm{c}$ & 1.0 & - \\
\hline $\mathrm{C} 22: 0$ & 1.5 & 0.2 \\
\hline $\mathrm{C} 22 \mathrm{:} 113 \mathrm{c}$ & 45.7 & - \\
\hline $\mathrm{C} 22: 213 \mathrm{c}, 16 \mathrm{c}$ & 1.8 & - \\
\hline $\mathrm{C} 22: 313 \mathrm{c}, 16 \mathrm{c}, 19 \mathrm{c}$ & 1.2 & - \\
\hline $\mathrm{C} 24: 115 \mathrm{c}$ & 2.5 & - \\
\hline Unknown (sum) & 1.3 & 0.1 \\
\hline$\Sigma \mathrm{sat}^{\mathrm{b}}$ & 5.9 & 16.0 \\
\hline$\Sigma$ monounsat $^{\mathrm{c}}$ & 61.6 & 23.6 \\
\hline$\Sigma$ trienes $^{\mathrm{d}}$ & 14.2 & 7.7 \\
\hline$\Sigma$ polyunsat $^{\mathrm{e}}$ & 31.2 & 60.3 \\
\hline$\Sigma \mathrm{C} 20+{ }^{\mathrm{f}}$ & 59.9 & 0.6 \\
\hline
\end{tabular}

${ }^{a}$ For example, C18:1 9c signifies an 18 carbon fatty acid chain with one $c i s(\mathrm{c})$ double bond located at carbon 9 (methyl 9Z-octadecenoate; methyl oleate)

${ }^{\mathrm{b}} \Sigma$ sat $=\mathrm{C} 14: 0+\mathrm{C} 16: 0+\mathrm{C} 18: 0+\mathrm{C} 20: 0+\mathrm{C} 22: 0$

c $\Sigma$ monounsat $=\mathrm{C} 16: 1+\mathrm{C} 18: 1+\mathrm{C} 20: 1+\mathrm{C} 22: 1+\mathrm{C} 24: 1$

${ }^{\mathrm{d}} \Sigma$ trienes $=\mathrm{C} 18: 3+\mathrm{C} 22: 3$

e $\Sigma$ polyunsat $=\Sigma$ trienes $+\mathrm{C} 18: 2+\mathrm{C} 20: 2+\mathrm{C} 22: 2$

${ }^{\mathrm{f}} \Sigma \mathrm{C} 20+=\mathrm{C} 20: 0+\mathrm{C} 20: 1+\mathrm{C} 20: 2+\mathrm{C} 22: 0+\mathrm{C} 22: 1+$ $\mathrm{C} 22: 2+\mathrm{C} 22: 3+\mathrm{C} 24: 1$

Southwest Research Institute (San Antonio, TX) utilizing an Ignition Quality Tester ${ }^{\mathrm{TM}}$ (IQT) following ASTM standard D6890. Sulfur (S, ppm) and phosphorous (P, mass $\%)$ contents were measured by Magellan Midstream Partners, L.P. (Kansas City, KS) according to ASTM standards D5453 and D4951, respectively. Gardner color was measured on a Lovibond 3-Field Comparator from Tintometer, Ltd. (Salisbury, England) following AOCS official method Td 1a-64.

Average calculated molecular weight $\left(\mathrm{MW}_{\text {calc }}, \mathrm{g} \mathrm{mol}^{-1}\right)$ was determined by a weighted average method utilizing the FA profiles depicted in Table 2. For the sake of providing calculated MW values that were not artificially low, unknown constituents were assumed to be erucic and oleic acids in the cases of wild mustard and soybean oils, respectively.

\section{Results and Discussion}

\section{Identification of Wild Mustard}

Although wild mustard is generally accepted as $S$. arvensis in Brazil, based on its morphological characteristics [4], the counts of prophase and metaphase mitotic chromosome spreads from root tips revealed a chromosome number (2n) of 36, which is characteristic of B. juncea [9]. A chromosome number of (2n) 18 has been reported for $S$. arvensis [10]. There is no record of the occurrence of $B$. juncea as a weed in Brazil, nor is it cultivated for seed production in Brazil. Since identification based on chromosome number was limited only to the population collected from the municipality of Viçosa (Brazil), it is not certain whether populations occurring elsewhere in Brazil belong to the same species, despite showing identical morphological characteristics.

Composition and Physical Properties

of Wild Mustard Oil

The oil content of dried wild mustard seeds was 37.9 wt.\% (Table 3), which was significantly higher than the typical range reported for soybeans (18-22 wt.\%) [11] and characteristic of the Brassicaceae family [2, 12-14]. The primary FA in WMO was erucic acid (C22:1 13c; 45.7 wt.\%), along with linoleic (C18:2 9c, 12c; 14.2 wt.\%) and linolenic (C18:3 9c, 12c, 15c; 13.0 wt.\%) acids (Table 2). Minor FA included oleic (C18:1 9c; 6.8 wt.\%), gondoic (C20:1 11c; 5.3 wt.\%), palmitic (C16:0; 2.6 wt.\%), and nervonic $(\mathrm{C} 24: 115 \mathrm{c} ; 2.5$ wt.\%) acids. These results concur with previous reports on the FA profile of B. juncea [1214]. The overall saturated and polyunsaturated FA contents of WMO were relatively low (5.9 and $31.2 \mathrm{wt} . \%$, respectively; Table 2) in comparison to SBO (16.0 and 60.3 wt.\%). Correspondingly, the monounsaturated FA content of WMO (61.6 wt.\%) was considerably higher than that for SBO (23.6 wt.\%). As a result of its low polyunsaturated content, WMO exhibited an IV of $112 \mathrm{~g} \mathrm{I}_{2} / 100 \mathrm{~g}$ (Table 3).

The Gardner color of crude WMO was 11 (1 is lightest, 18 is darkest), which was significantly darker than that obtained for RBD SBO (1, Table 3). The free fatty acid (FFA) content of crude WMO, as measured by AV, was $0.55 \mathrm{mg} \mathrm{KOH} \mathrm{g}^{-1}$ (Table 3). The average MW of WMO calculated from its FA profile was $979.57 \mathrm{~g} \mathrm{~mol}^{-1}$ (Table 3), which was higher than SBO (872.95 $\mathrm{g} \mathrm{mol}^{-1}$ ) due to the presence of erucic acid and other FA with 20 or more carbons.

Wild mustard oil principally contained $\alpha-(200 \mathrm{ppm})$ and $\gamma-(585 \mathrm{ppm})$ tocopherols, with the $\beta$ - $(1 \mathrm{ppm})$ and $\delta$ - $(14 \mathrm{ppm})$ homologues present at significantly lower 
Table 3 Physical properties of wild mustard (WMO) and soybean (SBO) oils

\begin{tabular}{llc}
\hline & Crude WMO & RBD SBO \\
\hline Oil content (wt.\%) & 37.9 & $18-22^{\mathrm{a}}$ \\
$\mathrm{MW}_{\text {calc }}\left(\mathrm{g} \mathrm{mol}^{-1}\right)$ & 979.57 & 872.95 \\
Gardner color & 11 & 1 \\
Cloud point $\left({ }^{\circ} \mathrm{C}\right)$ & n.d. & $-7(1)$ \\
Pour point $\left({ }^{\circ} \mathrm{C}\right)$ & $-16(1)$ & $-9(1)$ \\
Oxidative stability & & \\
Induction period, $110{ }^{\circ} \mathrm{C}(\mathrm{h})$ & $5.9(0.1)$ & $8.3(0.2)$ \\
Onset temperature $\left({ }^{\circ} \mathrm{C}\right)$ & $178.4(0.2)$ & $181.7(0.3)$ \\
Kinematic viscosity $\left(\mathrm{mm}^{2} \mathrm{~s}^{-1}\right)$ & & \\
$25{ }^{\circ} \mathrm{C}$ & $73.02(0.01)$ & $52.11(0.09)$ \\
$40{ }^{\circ} \mathrm{C}$ & $41.23(0.04)$ & $31.49(0.03)$ \\
$100{ }^{\circ} \mathrm{C}$ & $9.71(0.01)$ & $7.67(0.01)$ \\
Viscosity index & 233 & 228 \\
Specific gravity $\left({ }^{\circ} \mathrm{C}\right)$ & & \\
25 & $0.908(0.001)$ & $0.919(0.001)$ \\
40 & $0.899(0.001)$ & $0.910(0.001)$ \\
Sulfur (ppm) & 18 & 1 \\
Phosphorous $(\mathrm{mass} \%)$ & 0.0003 & 0.0000 \\
Lubricity, $60{ }^{\circ} \mathrm{C}(\mu \mathrm{m})$ & $155(3)$ & $124(2)$ \\
Acid value $\left(\mathrm{mg} \mathrm{KOH} \mathrm{g}{ }^{-1}\right)$ & $0.55(0.03)$ & $0.03(0.03)$ \\
Iodine value $\left(\mathrm{g} \mathrm{I}_{2} / 100 \mathrm{~g}\right)$ & 112 & 131 \\
\hline Values in $\left.{ }^{\circ}\right)$ & & \\
\hline
\end{tabular}

Values in parentheses are standard deviations from the reported means ( $n=3 ; n=2$ in the case of lubricity)

$R B D$ refers to refined, bleached, and deodorized; $n . d$. not determined due to color of oil

${ }^{\text {a }}$ From Ref. [11]

concentrations (Table 4). The total tocopherol content was $800 \mathrm{ppm}$, which was higher than that reported for crude commodity vegetable oils such as palm (642 ppm, combined), sunflower (546 ppm), and safflower (413 ppm) oils, with the notable exception of soybean [15]. The combined tocopherol content of RBD SBO was reported as $757 \mathrm{ppm}$ [16] and that of SME prepared from crude SBO was 1,301 ppm [17].

The primary phytosterols in WMO were $\beta$-sitosterol $\left(5.99 \mathrm{mg} \mathrm{g}^{-1}\right)$ and campesterol $\left(3.59 \mathrm{mg} \mathrm{g}^{-1}\right)$, with brassicasterol $\left(1.34 \mathrm{mg} \mathrm{g}^{-1}\right), \quad \delta 5$-avenasterol $\quad(0.20 \mathrm{mg}$ $\left.\mathrm{g}^{-1}\right), \quad \delta 7$-avenasterol $\left(0.13 \mathrm{mg} \mathrm{g}^{-1}\right), \quad$ and clerosterol $\left(0.06 \mathrm{mg} \mathrm{g}^{-1}\right)$ accounting for the remaining phytosterol content (Table 4). The combined phytosterol concentration was $11.31 \mathrm{mg} \mathrm{g}^{-1}$, which was higher than that previously found for RBD SBO (4.29 $\mathrm{mg} \mathrm{g} \mathrm{g}^{-1}$ ) [16]. As was the case here, brassicasterol normally comprises $5-20 \%$ of total phytosterols in oils from members of the Brassicaceae family (11.8\% for WMO) [18].

Seed meals from members of the Brassicaceae family are known to contain significant quantities of sulfur-containing
Table 4 Tocopherol (ppm) and phytosterol $\left(\mathrm{mg} \mathrm{g}^{-1}\right)$ contents of wild mustard oil (WMO) and the corresponding methyl esters

\begin{tabular}{lcc}
\hline & WMO & WMME \\
\hline Tocopherols & $200(4)$ & $109(4)$ \\
$\alpha$-Tocopherol & $1(0)$ & $1(1)$ \\
$\beta$-Tocopherol & $14(0)$ & $12(0)$ \\
$\delta$-Tocopherol & $585(9)$ & $459(10)$ \\
$\gamma$-Tocopherol & $800(13)$ & $582(13)$ \\
$\Sigma$ Toco & & \\
Phytosterols & $1.34(0.04)$ & $1.37(0.04)$ \\
Brassicasterol & $3.59(0.04)$ & $3.70(0.12)$ \\
Campesterol & 0 & $0.05(0.00)$ \\
Campestanol & $5.99(0.04)$ & $6.13(0.27)$ \\
$\beta$-Sitosterol & $0.20(0.01)$ & $0.25(0.01)$ \\
$\delta 5$-Avenasterol & $0.13(0.01)$ & $0.12(0.03)$ \\
$\delta 7$-Avenasterol & $0.06(0.01)$ & $0.06(0.00)$ \\
Clerosterol & $11.31(0.13)$ & $11.67(0.47)$ \\
$\Sigma$ Phyto &
\end{tabular}

Numbers in parentheses represent the standard deviation from the reported means $(n=3)$

$\Sigma$ toco total tocopherol content; $\Sigma$ phyto total phytosterol content

glucosinolates. Although glucosinolates and their various decomposition products are polar, a small quantity is nevertheless transferred to the lipid phase during separation of vegetable oil from the meal, as evidenced by the sulfur content of crude WMO (18 ppm; Table 3). In addition, crude WMO contained a very low amount of phosphorous (0.0003 mass \%; Table 3).

The low temperature operability of crude WMO was characterized by a $\mathrm{PP}$ of $-16^{\circ} \mathrm{C}$, which was lower than that obtained for RBD SBO $\left(-9{ }^{\circ} \mathrm{C}\right)$. The CP of WMO was not determined as a result of the darkness of the oil (Gardner color of 11), but RBD SBO had a CP of $-7{ }^{\circ} \mathrm{C}$ (Table 3). The relatively low level of saturated FA contained in WMO (5.9 wt.\%; Table 1) versus SBO (16.0 wt.\%) is attributed to its enhanced low temperature operability. A previous study elucidated a statistically significant relationship between saturated FA content and low temperature properties [19].

The oxidative stability of WMO was determined by the Rancimat (EN 14112) and PDSC methods. The IP (EN 14112) and OT (PDSC) values were $5.9 \mathrm{~h}$ and $178.4{ }^{\circ} \mathrm{C}$ (Table 3), respectively. These values were lower than those obtained for SBO $\left(8.3 \mathrm{~h}\right.$ and $\left.181.7^{\circ} \mathrm{C}\right)$. The difference in stability to oxidation may be attributed to the difference in trienoic (3 double bonds) FA content between the oils, as WMO contained $14.2 \mathrm{wt} \%$ of these constituents as opposed to 7.7 wt.\% for SBO (Table 2). Trienoic FA are particularly vulnerable to autoxidation, as evidenced by the relative rates of oxidation of unsaturated esters: 1 for ethyl 
oleate, 41 for ethyl linoleate, and 98 for ethyl linolenate [15].

The kinematic viscosity of WMO was higher than that for SBO over a wide range of temperatures $\left(25-100{ }^{\circ} \mathrm{C}\right.$; Table 3) as a result of its high content of FA with 20 or more carbons. Kinematic viscosity is dependent upon the constituent FA contained within vegetable oils. Fatty acids of longer-chain lengths are progressively more viscous, as evidenced by the kinematic viscosities $\left(40{ }^{\circ} \mathrm{C}\right)$ of methyl esters of palmitic $\left(3.67 \mathrm{~mm}^{2} \mathrm{~s}^{-1}\right)$, oleic $\left(4.51 \mathrm{~mm}^{2} \mathrm{~s}^{-1}\right)$, gondoic $\left(5.77 \mathrm{~mm}^{2} \mathrm{~s}^{-1}\right)$, and erucic $\left(7.33 \mathrm{~mm}^{2} \mathrm{~s}^{-1}\right)$ acids [20]. The kinematic viscosity of $\mathrm{WMO}$ at 25,40 , and $100{ }^{\circ} \mathrm{C}$ was $73.02,41.23$, and $9.71 \mathrm{~mm}^{2} \mathrm{~s}^{-1}$ (Table 3), respectively, which resulted in a VI of 233. The specific gravities of WMO at 25 and $40{ }^{\circ} \mathrm{C}$ were 0.908 and 0.899 , respectively, which were nearly indistinguishable from SBO at both 25 and $40{ }^{\circ} \mathrm{C}$ (see Table 3). The wear scar generated by WMO according to the HFRR lubricity method (ASTM D6079; $60{ }^{\circ} \mathrm{C}$ ) was $155 \mu \mathrm{m}$, which was similar to that obtained for SBO (124 $\mu \mathrm{m}$; Table 3$)$.

\section{Preparation of Wild Mustard Oil Methyl Esters}

Wild mustard oil methyl esters (WMME) were prepared in high yield (94 wt.\%) from crude WMO utilizing classic homogenous base-catalyzed reaction conditions reported previously [2, 19, 21]. The methyl esters prepared from crude WMO satisfied the specifications for free and total glycerol in both the ASTM D6751 and EN 14214 biodiesel standards (Table 1) with values of 0.002 and 0.224 mass $\%$, respectively (Table 5). The low AV of crude WMO facilitated direct base-catalyzed transesterification without the need for acid-pretreatment. The average MW calculated from the FA profile was $327.87 \mathrm{~g} \mathrm{~mol}^{-1}$ (Table 5), which as observed in the case of the vegetable oils was higher than that calculated for SME $\left(292.33 \mathrm{~g} \mathrm{~mol}^{-1}\right)$. The Gardner color of WMME was 10 (Table 5).

The ${ }^{1} \mathrm{H}-\mathrm{NMR}$ and FT-IR spectra of WMME confirm the structure as FAME and are qualitatively similar to the corresponding spectra of SME and agree with prior literature [21]. Despite the divergent FA profiles of WMME and SME, these materials contained identical functional groups (methyl esters, olefinic, allylic, bis-allylic, methylene, and terminal methyl groups), thus resulting in similar ${ }^{1} \mathrm{H}-\mathrm{NMR}$ and FT-IR spectra. For example, both WMME and SME contained methyl ester moieties that were prominently indicated in ${ }^{1} \mathrm{H}-\mathrm{NMR}$ spectra by strong singlets at $3.67 \mathrm{ppm}$ and in FT-IR spectra by prominent carbonyl signals at $1,742 \mathrm{~cm}^{-1}$.

Preparation of WMME yielded a reduction in tocopherol content of $27 \%$ versus crude WMO, whereas phytosterol content was retained (Table 4). Although there appeared to be an increase in phytosterols upon conversion to WMME,
Table 5 Properties of wild mustard (WMME) and soybean oil methyl esters (SME)

\begin{tabular}{lll}
\hline & WMME & SME \\
\hline $\mathrm{MW}_{\text {calc }}\left(\mathrm{g} \mathrm{mol}^{-1}\right)$ & 327.87 & 292.33 \\
Acid value $\left(\mathrm{mg} \mathrm{KOH} \mathrm{g}^{-1}\right)$ & $0.06(0.05)$ & $0.01(0.01)$ \\
Gardner color & 10 & 1 \\
Free glycerol (mass \%) & 0.002 & 0.010 \\
Total glycerol (mass \%) & 0.224 & 0.156 \\
Cloud point $\left({ }^{\circ} \mathrm{C}\right)$ & $4(1)$ & $0(1)$ \\
Pour point $\left({ }^{\circ} \mathrm{C}\right)$ & $-21(1)$ & $-3(1)$ \\
Cold filter plugging point $\left({ }^{\circ} \mathrm{C}\right)$ & $-3(1)$ & $-4(1)$ \\
Oxidative stability & & \\
Induction period, $110{ }^{\circ} \mathrm{C}(\mathrm{h})$ & $4.8(0.1)$ & $5.0(0.1)$ \\
Onset temperature $\left({ }^{\circ} \mathrm{C}\right)$ & $170.2(1.2)$ & $171.6(1.5)$ \\
Kinematic viscosity, $40{ }^{\circ} \mathrm{C}\left(\mathrm{mm}{ }^{2} \mathrm{~s}^{-1}\right)$ & $5.33(0.01)$ & $4.12(0.01)$ \\
Specific gravity $\left({ }^{\circ} \mathrm{C}\right)$ & & \\
25 & $0.874(0.001)$ & $0.919(0.001)$ \\
40 & $0.863(0.001)$ & $0.910(0.001)$ \\
Wear scar, HFRR, $60{ }^{\circ} \mathrm{C}(\mu \mathrm{m})$ & $151(7)$ & $135(5)$ \\
Sulfur (ppm) & 11 & 1 \\
Phosphorous $(\mathrm{mass} \%)$ & 0.0002 & 0.0000 \\
Derived cetane number & 61.1 & $54.0^{\mathrm{a}}$ \\
Iodine value $(\mathrm{g} \mathrm{I} / 100 \mathrm{~g})$ & 112 & 131 \\
\hline
\end{tabular}

Values in parentheses are standard deviations from the reported means ( $n=3 ; n=2$ for lubricity)

${ }^{\text {a }}$ From Ref. [22]

the difference in content between WMME $\left(11.67 \mathrm{mg} \mathrm{g}^{-1}\right)$ and WMO (11.31 $\mathrm{mg} \mathrm{g}^{-1}$ ) was not statistically significant, as indicated by overlapping values when standard deviations were taken into consideration. The concentration of combined tocopherols was reduced from 800 to $582 \mathrm{ppm}$ (Table 4). Tocopherols and phytosterols are non-polar and should essentially remain soluble in hydrophobic materials such as biodiesel as opposed to partitioning into polar glycerolic or aqueous phases during purification. The presence of tocopherols in biodiesel is normally advantageous, as they are reported to inhibit oxidation [17].

\section{Physical Properties of Wild Mustard Oil Methyl Esters}

The properties of WMME are summarized in Table 5. Also depicted in Table 5 for comparison are the properties of SME. Selected specifications relevant to the current study from biodiesel fuel standards ASTM D6751 and EN 14214 are summarized in Table 1 for comparison to WMME.

The DCN of WMME was 61.1 (Table 5), which was above the minimum limits of 47 and 51 specified in ASTM D6751 and EN 14214, respectively. Results generated by ASTM D6890 (DCN) generally correlate with CN determination by ATSM D613. For comparison, a previous 
study determined that the DCN of SME was 54.0 [22]. The high DCN of WMME may be explained by the presence of longer-chain FAME (20+ carbons) such as methyl erucate and gondoate, as longer-chain FAME are known to have higher $\mathrm{CN}$ than shorter-chain FAME [23]. As seen from Table 2, WMME contained 59.9 wt.\% FAME with 20 or more carbons, as opposed to $0.6 \mathrm{wt} . \%$ in the case of SME.

The kinematic viscosity of WMME was $5.33 \mathrm{~mm}^{2} \mathrm{~s}^{-1}$ at $40{ }^{\circ} \mathrm{C}$ (Table 5), which was within the range specified in ASTM D6751 but higher than the maximum limit in EN 14214 (Table 1). The high kinematic viscosity of WMME was a result of the presence of longer-chain $(\mathrm{C} 20+)$ FAME. The kinematic viscosity of methyl erucate has been reported as $7.33 \mathrm{~mm}^{2} \mathrm{~s}^{-1}$ and that of methyl gondoate as $5.77 \mathrm{~mm}^{2} \mathrm{~s}^{-1}$ [20]. These species, together with other FAME in the $\mathrm{C} 20+$ range, constituted 59.9 wt.\% of the FA profile (Table 2) of WMO. The kinematic viscosity of SME was $4.12 \mathrm{~mm}^{2} \mathrm{~s}^{-1}$, which was in agreement with the range reported in previous studies [17, 19, 21, 24, 25]. Blending WMME with less viscous biodiesel fuels such as SME represents a potential strategy to satisfy the EN 14214 kinematic viscosity specification.

The oxidative stability of WMME was $4.8 \mathrm{~h}$ (Table 5), as measured by the Rancimat method (IP; EN 14112). Addition of antioxidants or blending with more oxidatively stable feedstocks would be necessary to satisfy the oxidative stability requirement (IP $>6 \mathrm{~h}$ ) contained in EN 14214. WMME was acceptable according to the less stringent oxidative stability specification (IP $>3 \mathrm{~h}$ ) in ASTM D6751. The IP of SME was similar with a value of $5.0 \mathrm{~h}$. It should be noted that the IP of WMME was in excess of IP reported for individual unsaturated FAME [26], suggesting that native tocopherols (Table 4) were in part responsible for the observed oxidative stability of WMME [16]. The similarity in oxidative stability between WMME and SME as determined by the Rancimat method was corroborated by the results obtained from PDSC, as indicated by similar OT values of 170.2 and $171.6^{\circ} \mathrm{C}$, respectively (Table 5). The OT is the temperature at which a rapid increase in the rate of oxidation is observed at a constant, high pressure $(378.95 \mathrm{kPa})$. A high OT would suggest high oxidative stability and vice versa.

Although ASTM D6751 does not contain an IV specification, EN 14214 limits IV to a maximum value of $120 \mathrm{~g} \mathrm{I}_{2} / 100 \mathrm{~g}$. This restriction disqualifies $\mathrm{SME}$ in the neat form in Europe, as it has an IV in excess of 120 (131). However, WMME was below the maximum limit with a value of 112. Despite the significant difference in IV between WMME and SME, the oxidative stabilities (IP, OT) of these materials were essentially indistinguishable.

Both ASTM D6751 and EN 14214 restrict AV to a maximum value of $0.50 \mathrm{mg} \mathrm{KOH} \mathrm{g}{ }^{-1}$. The AV of WMME was significantly below the specified limit with a value of
$0.06 \mathrm{mg} \mathrm{KOH} \mathrm{g}^{-1}$. The AV of SME was satisfactory as well with a value of $0.01 \mathrm{mg} \mathrm{KOH} \mathrm{g}^{-1}$.

Sulfur content is limited in ASTM D6751 and EN 14214 to maximum values of 15 and $10 \mathrm{ppm}$, respectively. The sulfur content of WMME was 11 ppm (Table 5), which was below the specified limit in ASTM D6751 but higher than the maximum allowable limit in EN 14214. The sulfur content of crude WMO (18 ppm; Table 3) was responsible for the relatively high sulfur content of WMME. Methods to reduce the sulfur content of WMME may include the refining, bleaching, and deodorization process used to purify crude commodity vegetable oils and/or blending with biodiesel fuels with lower sulfur contents. SME was essentially free of sulfur content (1 ppm). Phosphorous content is limited as well in ASTM D6751 and EN 14214 to a maximum value of 0.001 mass $\%$. The phosphorous content of WMME (0.0002 mass\%; Table 5) was below the maximum allowable limits prescribed in ASTM D6751 and EN 14214. SME contained no phosphorous.

The specific gravity of WMME at 25 and $40{ }^{\circ} \mathrm{C}$ was 0.874 and 0.863 (Table 5), respectively. For comparison, the specific gravity of SME at 25 and $40{ }^{\circ} \mathrm{C}$ was 0.919 and 0.910 , respectively. As can be seen, lower values were obtained at the higher temperature for both fuel samples. Specific gravity is not specified in ASTM D6751 or EN 14214.

Lubricity (ASTM D6079) is not specified in ASTM D6751 or EN 14214 but is included in the petrodiesel standards ASTM D975 and EN 590 with maximum prescribed wear scars of 520 and $460 \mu \mathrm{m}$, respectively. Fuels with poor lubricity can cause failure of diesel engine parts that rely on lubrication from fuels, such as fuel pumps and injectors [1]. The wear scar generated by WMME by the high-frequency reciprocating rig (HFRR) lubricity method ASTM D6079 $\left(60^{\circ} \mathrm{C}\right)$ was $151 \mu \mathrm{m}$ (Table 5). As expected, the lubricity of WMME was considerably below the maximum limits set forth in the aforementioned petrodiesel standards, which was in agreement with several previous studies indicating that biodiesel possessed inherent lubricity $[2,21,24,25]$. The wear scar generated by SME was $135 \mu \mathrm{m}$, which was also satisfactory according to the petrodiesel standards.

The low temperature operability of WMME was determined by CP, CFPP and PP. As seen in Table 5, WMME provided CP, PP and CFPP values of $4,-21$ and $-4{ }^{\circ} \mathrm{C}$, respectively. The corresponding values for $\mathrm{SME}$ were 0 , -3 , and $-4{ }^{\circ} \mathrm{C}$. The unusually large difference between $\mathrm{CP}$ and PP of WMME $\left(25^{\circ} \mathrm{C}\right)$ indicated that a small amount of high-melting constituent(s) were crystallizing at temperatures significantly above the PP. Such constituents could theoretically be saturated FAME, saturated mono- or di-acylglycerols, phospholipids, and/or phytosterols. Phospholipids were not suspected, as phosphorous comprised 
only a trace amount (0.0002 mass \%; Table 5) of WMME. Saturated mono- and di-acylglycerols are reported to have substantial deleterious effects on CP of SME at concentrations as low as $0.2 \mathrm{wt} . \%$ [27]. The melting points of 1-monopalmitin, 1-monostearin, 1,3-dipalmitin, and 1,3distearin are $120,75,74$, and $80{ }^{\circ} \mathrm{C}$ [28]. It is speculated that mono- and di-acylglycerols were at least in part responsible for the high CP of WMME, as indicated by the bond glycerol (bond glycerol $=$ mono- + di- + tri-acylglycerols $=$ total glycerol - free glycerol) content of WMME (0.222 mass \%). The saturated FAME content of WMME was 5.9 wt. $\%$ of the FA profile (Table 2). As the chain length of saturated FAME is increased, a concomitant increase in melting point is observed, as indicated by the melting points of saturated methyl esters of palmitic (C16:0; $\left.31{ }^{\circ} \mathrm{C}\right)$, stearic $\left(\mathrm{C} 18: 0 ; 39{ }^{\circ} \mathrm{C}\right)$, arachidic $\left(\mathrm{C} 20: 0 ; 46{ }^{\circ} \mathrm{C}\right)$, and behenic $\left(\mathrm{C} 22: 0 ; 54{ }^{\circ} \mathrm{C}\right)$ acids [28]. WMME contained a combined 2.3 wt. $\%$ of methyl arachidate and methyl behenate, whereas these constituents only comprised 0.4 wt.\% of SME. The content of these particularly high-melting FAME may also in part explain the high CP of WMME despite the overall higher level of saturated FAME in SME (16.0 wt.\%; Table 2). It was also speculated that the content of phytosterols (11.67 $\mathrm{mg} \mathrm{g}^{-1}$; Table 4) may in part be responsible for the high CP of WMME. For comparison, RBD SBO from which SME was prepared was reported to contain $4.29 \mathrm{mg} \mathrm{g}^{-1}$ phytosterols [16]. Phytosterols, which in vegetable oils are normally present as sterol glucosides (SG), are sparingly soluble in biodiesel and have melting points around $240{ }^{\circ} \mathrm{C}$ [29]. The deleterious effects of SG on the low temperature operability of biodiesel obtained from soybean and palm oils has been reported [30].

Acknowledgment The authors acknowledge Benetria N. Banks and Kathy Rennick for excellent technical assistance. This study was supported in part by the Brazilian government [CAPES (Coordenação de Aperfeiçoamento de Pessoal do Ensino Superior) and CNPq (Conselho Nacional de Desenvolvimento Cientifico e Tecnológico)].

\section{References}

1. Knothe G, Van Gerpen J, Krahl J (2005) The biodiesel handbook. AOCS Press, Urbana

2. Moser BR (2009) Biodiesel production, properties, and feedstocks. In vitro Cell Dev Biol Plant 45:229-266

3. Retka-Schill S (2008) Walking a tightrope. Biodiesel Mag 5(3):64-70

4. Lorenzi H (2000) Plantas daninhas do Brasil. Instituto Plantarum de Estudos de Flora Ltda, Nova Odessa

5. Lima AO (2006) Soil biofumigation with Brassica rapa to control plant nematodes. M.S. Thesis, Universidade Federal de Viçosa, MG, Brazil

6. Andras SC, Hartman TPV, Marshall JA, Marchant R, Power JB, Cocking EC, Davey MR (1999) A drop-spreading technique to produce cytoplasm-free mitotic preparations from plants with small chromosomes. Chromosome Res 7:641-647
7. Kim JS, Childs KL, Islam-Faridi MN, Menz MA, Klein RR (2002) Integrated karyotyping of sorghum by in situ hybridization of landed BACs. Genome 45:402-412

8. Dutta PC, Normén L (1998) Capillary column gas-liquid chromatographic separation of $\Delta 5$-unsaturated and saturated phytosterols. J Chromatogr A 816:177-184

9. Banga SS (1988) C-genome chromosome substitution lines in Brassica juncea (L.) Coss. Genetica 77:81-84

10. Scheffler JA, Dale PJ (1994) Opportunities for gene transfer from transgenic oilseed rape (Brassica napus) to related species. Transgenic Res 3:263-278

11. Chung J, Babka HL, Graef GL, Staswick PE, Lee DJ, Cregan PB, Shoemaker RC, Specht JE (2003) The seed protein, oil, and yield QTL on soybean linkage group I. Crop Sci 43:10531067

12. Sinha S, Jha JK, Maiti MK, Basu A, Mukkopadhyay UK, Sen SK (2007) Metabolic engineering of fatty acid biosynthesis in Indian mustard (Brassica juncea) improves nutritional quality of seed oil. Plant Biotechnol Rep 1:185-197

13. George L, Abraham V, Suryavanshi DR, Sipahimalani AT, Srinivasan VT (2006) Yield, oil content and fatty acid composition evaluated in androgenetic plants in Brassica juncea. Plant Breed 98:72-74

14. Bhat MA, Gupta ML, Banga SK, Raheja RK, Banga SS, Rakow G (2008) Erucic acid heredity in Brassica juncea-some additional information. Plant Breed 121:456-458

15. Frankel EN (2004) Lipid oxidation. The Oily Press, Bridgewater

16. Moser BR, Shah SN, Winkler-Moser JK, Vaughn SF, Evangelista RL (2009) Composition and physical properties of cress (Lepidium sativum L.) and field pennycress (Thlaspi arvense L.) oils. Ind Crops Prod (in press). doi:10.1016/j.indcrop.2009.03.007

17. Moser BR (2008) Efficacy of myricetin as an antioxidant in methyl esters of soybean oil. Eur J Lipid Sci Technol 110:11671174

18. Phillips KM, Ruggio DM, Toivo JI, Swank MA, Simpkins AH (2002) Free and esterified sterol composition of edible oils and fats. J Food Compost Anal 15:123-142

19. Moser BR (2008) Influence of blending canola, palm, soybean, and sunflower oil methyl esters on fuel properties of biodiesel. Energy Fuels 22:4301-4306

20. Knothe G, Steidley KR (2005) Kinematic viscosity of biodiesel fuel components and related compounds. Influence of compound structure and comparison to petrodiesel fuel standards. Fuel 84:1059-1065

21. Moser BR, Haas MJ, Winkler JK, Jackson MA, Erhan SZ, List GR (2007) Evaluation of partially hydrogenated methyl esters of soybean oil as biodiesel. Eur J Lipid Sci Technol 109:17-24

22. Knothe K, Sharp CA, Ryan TWIII (2006) Exhaust emissions of biodiesel, petrodiesel, neat methyl esters, and alkanes in a new technology engine. Energy Fuels 20:403-408

23. Knothe G, Matheaus AC, Ryan TWIII (2003) Cetane numbers of branched and straight-chain fatty esters determined in an ignition quality tester. Fuel 82:971-975

24. Moser BR, Cermak SC, Isbell TA (2008) Evaluation of castor and lesquerella oil derivatives as additives in biodiesel and ultralow sulfur diesel fuels. Energy Fuels 22:1349-1352

25. Moser BR, Erhan SZ (2008) Branched chain derivatives of alkyl oleates: tribological, rheological, oxidation, and low temperature properties. Fuel 87:2253-2257

26. Moser BR (2009) Comparative oxidative stability of fatty acid alkyl esters by accelerated methods. J Am Oil Chem Soc 86:699706

27. Yu L, Lee I, Hammond EG, Johnson LA, Van Gerpen JH (1998) The influence of trace components on the melting point of methyl soyate. J Am Oil Chem Soc 75:1821-1824 
28. Anonymous (2007) Part 2: physical properties of organic compounds. In: Gunstone FD, Harwood JL, Dijkstra AJ (eds) The lipid handbook, 3rd edn. CRC Press, Boca Raton, pp 139-435

29. Lee I, Pfalzgraf LM, Poppe GB, Powers E, Haines T (2007) The role of sterol glucosides on filter plugging. Biodiesel Mag 4:105112
30. Van Hoed V, Zyaykina N, De Greyt W, Maes J, Verhe R, Demeestere K (2008) Identification and occurrence of steryl glucosides in palm and soy biodiesel. J Am Oil Chem Soc 85:701-709 